\title{
BRAF Mutation (V600E) Prevalence in Mexican Patients Diagnosed with Melanoma
}

\author{
Priscilla Denise Zepeda-Lopez ${ }^{a}$ Julio Cesar Salas-Alanis ${ }^{c}$ \\ Sonia Toussaint-Caire ${ }^{a}$ Daniela Gutierrez-Mendoza ${ }^{a}$ \\ Elisa Vega-Memije ${ }^{a}$ Saúl Lino Silva ${ }^{b}$ Oscar Raul Fajardo-Ramírez ${ }^{c}$ \\ Gregorio Alcazar $^{d} \quad$ María Guadalupe Moreno-Treviño ${ }^{c}$ \\ Hugo Alberto Barrera Saldaña ${ }^{d}$ \\ ${ }^{a}$ Servicio de Dermatología, Hospital General 'Dr. Manuel Gea González', and \\ ${ }^{\text {b}}$ Departamento de Patología, Instituto Nacional de Cancerología, Mexico City, \\ 'Departamento de Ciencias Básicas, Universidad de Monterrey, San Pedro Garza García, \\ and ${ }^{d}$ Vitagénesis, S.A. de C.V., Monterrey, Mexico
}

\section{Key Words}

Melanoma $\cdot B R A F \cdot$ V600E mutation $\cdot$ Mexican patients

\begin{abstract}
Background: B-Raf is a serine/threonine protein kinase activating the MAP kinase/ERK-signaling pathway. It has been shown that $50 \%$ of melanomas harbor activating BRAF mutations, with over $90 \%$ being the V600E mutation. Objective: The goal of this research was to determine the prevalence of the BRAF V600E mutation in patients from Central Mexico diagnosed with primary melanoma. Methods: Skin biopsies from 47 patients with melanoma were obtained from the dermatology department of the Hospital General 'Dr. Manuel Gea González' in Mexico City. For BRAF mutation determination, after DNA isolation, the gene region where the mutation occurs was amplified by PCR. Subsequently, the presence or absence of the V600E mutation was detected by Sanger sequencing performed at the private molecular diagnostic laboratory Vitagénesis in Monterrey, Mexico. Results: Of the 47 patients sampled, $6.4 \%$ harbored the V600E mutation. No statistical significance was found between mutations and the type of tumor.


Zepeda-Lopez et al:: BRAF Mutation (V600E) Prevalence in Mexican Patients Diagnosed with Melanoma

\section{Introduction}

Contrary to some types of cancer whose incidence has decreased due to prevention and early diagnosis, the incidence of melanoma has increased from 18.0 per 100,000 in 1999 to 22.2 per 100,000 in 2008 , even in countries with a low prevalence $[1,2]$. Only $5 \%$ of all dermatology malignancies are due to metastatic melanoma [3], but it is responsible for $80 \%$ of all deaths. Because of a delay in diagnosis, it is estimated that only $14 \%$ of patients survive 5 years after diagnosis [4]. Factors such as sun sensitivity, ultraviolet radiation exposure, and genetic predisposition have been associated with the development of melanoma [5].

In the genetic background, some rare activating mutations have been reported in genes such as the proto-oncogene $B R A F$, which is mutated in about $45 \%$ of cases in papillary thyroid cancer, $10 \%$ in colorectal cancer, and also with a low prevalence in other types of cancer including ovarian, breast, and lung cancer. In the case of melanoma, prevalence ranges from 33 to $70 \%$ [6]. This gene is involved in the activation of the mitogen-activated protein kinase pathway, playing an important role in melanoma genesis by regulating different cell functions such as proliferation, differentiation, and survival [7]. Mutations in this gene are related to poor prognosis in melanoma cases [8]; nevertheless, this protein have been used for the design of therapeutics molecules, opening a new window for dealing with this type of cancer [9]. According to Ernstoff [10], the response rate with this kind of molecules in a phase 1 study was $69 \%$. In another study, Yu et al. [11] showed BRAF inhibitor-induced tumor regression in $70 \%$ of patients with the mutation.

However, the function of $B R A F$ mutations has been a matter of controversy, as evidence supporting the involvement of these isoforms in the initiation and/or progression of melanoma has been published. In this context, while some researchers mentioned that mutations are necessary for the appearance of tumors [12], others say that the mutations are not present since the beginning, but are developed as the tumors progress [13]. Regarding this, a prevalence study on $B R A F$ mutation status in primary melanoma samples of patients from Northeast Mexico by Fajardo-Ramírez et al. [14] reported a prevalence of 70\% in the cases analyzed.

The objective of this study was to determine the status of the BRAF mutation V600E in patients diagnosed with melanoma attending a public clinic of dermatology located in Mexico City (Central Mexico), and to correlate it with the clinical and histopathological features of the malignancy.

\section{Materials and Methods}

\section{Samples}

Forty-seven melanoma samples were obtained between 2006 and 2012 from patients attending the dermatology service at the Hospital General 'Dr. Manuel Gea González' in Mexico City (Central Mexico). Inclusion criteria were pathological diagnosis of melanoma between 2001 and 2012, Mexican ancestry up to grandparents, and a biopsy or full processed specimen embedded in paraffin. Exclusion criteria were any other kind of skin cancer, fine needle biopsy, incomplete sample, non-Mexican ancestry, and skin metastases from another primary tumor different from melanoma. Clinical variables included sex, age at diagnosis, and anatomic site of the tumor. The latter was determined by the skin biopsy sent to the pathology laboratory and was classified into five different categories: (1) head, face or neck, (2) trunk, (3) arms, (4) legs, and (5) mucosa. 
Zepeda-Lopez et al:: BRAF Mutation (V600E) Prevalence in Mexican Patients Diagnosed with Melanoma

\section{BRAF Genotyping}

After appropriate pathological confirmation of melanoma, DNA extraction was performed using the QIAamp DNA FFPE Tissue kit following the manufacturer's instructions (Qiagen México S. de R.L. de C.V., Mexico City, Mexico). The BRAF mutation hotspot regions in exons 11 and 15 were amplified by PCR followed by the Sanger sequencing method in an Applied Biosystems 310 capillary electrophoresis apparatus (Life Sciences, Mexico City, Mexico) according to the manufacturer's instructions. The protocol was carried out in the Instituto Nacional de Cancerología in Mexico City and in Vitagénesis, S.A. de C.V., Monterrey, Mexico.

\section{Statistical Analysis}

Excel and SPSS were used to create the database and analyze differences between $B R A F$ V600E-positive and $B R A F$ V600E-negative cases. The results were expressed as frequencies or as percentages, and the association between the clinical characteristics of the samples and $B R A F$ V600E status was made using the $\chi^{2}$ or Fisher's exact test. All tests were interpreted based on a two-tailed hypothesis with a significance level of $\mathrm{p} \leq 0.05$.

\section{Results}

We analyzed the BRAF V600E status in 47 samples that fulfilled the inclusion criteria. The mean age of the patients was $54.5 \pm 19.7$ years, and 26 out of 47 (55.3\%) were women. Regarding origin, the Distrito Federal (DF) was the main place of origin, accounting for $66.0 \%(n=31)$ of cases, followed by the states of Mexico and Oaxaca with 10.6 and 8.5\%, respectively, with the majority of the population studied coming mainly from Central Mexico. The clinical and pathological characteristics are shown in table 1. The quality of DNA suitable for analysis was determined (data not shown).

With respect to the $B R A F$ V600E mutation, it was found that in 3 patients $(6.4 \%)$ it was positive, while in 44 patients (93.6\%) it was negative. Regarding gender distribution, there were 21 men (44.7\%) and 26 women (55.3\%), with the BRAF V600E mutation being positive in 1 out of 21 men (4.8\%) and in 2 out of 26 women (7.7\%) with no statistical difference. Tumor location sites were the head and neck in 9 (19.1\%), the trunk in 4 (8.5\%), the arms in $10(21.3 \%)$, and the legs in 24 (51.1\%); in the mucosa and in undetermined sites there were no cases. $B R A F$ status did not influence tumor location. With respect to clinical diagnosis and $B R A F$ status, there was no association either.

As to pathological characteristics, based on Breslow's thickness, it was observed that in 29 cases $(61.7 \%)$ the tumor was $\geq 1.01 \mathrm{~mm}$, with 1 case $(3.4 \%)$ being positive for the V600E mutation. The BRAF mutation did not influence Breslow's tumor thickness.

\section{Discussion}

The analysis of BRAF mutation V600E in samples from patients from Northeast Mexico diagnosed with primary melanoma found that $73 \%$ of patients harbored the V600E mutation [14]. The clinical implications of this type of studies are related to the evidence of improving melanoma treatment with $B R A F$ inhibitors [9]. Several studies have been carried out to evaluate the prevalence of $B R A F$ mutations in melanoma patients, with mutations on $B R A F$ ranging from 25 to $73 \%$ in several populations worldwide [5, 6]. 
Zepeda-Lopez et al:: BRAF Mutation (V600E) Prevalence in Mexican Patients Diagnosed with Melanoma

Contrary to Fajardo-Ramírez et al. [14], we found the V600E mutation in $6.4 \%(n=3)$ of patients. This difference can be explained based on the population screened, as we analyzed patients from Central Mexico, while Fajardo-Ramírez et al. screened patients from the Northeast, and Mexico's ethnic diversity is well known. Another possible explanation is the method used, as both studies used different genotyping methods. In this context, Yancovitz et al. [15] used two methods for screening this mutation, and found differences between mutant-specific PCR and conventional sequencing. They reported a 32\% prevalence by means of sequencing, and a prevalence of $76 \%$ using mutant-specific PCR. This study revealed a low BRAF mutation frequency in a population from Central Mexico. Additionally, determining the $B R A F$ status in early stages of the disease helps to identify those patients with high risk of developing metastatic melanoma for carrying this critical factor as well as patients who need special follow-up; also, the $B R A F$ status helps to identify who will benefit from $B R A F$ kinase inhibitor therapy.

Finally, we are planning further studies to describe not only the V600E mutation in melanoma patients from Mexico, but also to screen the entire gene in search for additional mutations that could be driving the tumor, in addition to studies comparing the prevalence of the $B R A F$ mutation and other genes involved in the mitogen-activated protein kinase pathway, between primary and metastatic melanoma in Mexican patients.

\section{Statement of Ethics}

Approval by the Ethics and Research Committees of the Hospital General 'Dr. Manuel Gea González’ was obtained.

\section{Disclosure Statement}

The authors have no financial or other conflicts of interest to declare. There was no funding source.

\section{References}

1 Romano E, Schwartz GK, Chapman PB, Wolchock JD, Carvajal RD: Treatment implications of the emerging molecular classification system for melanoma. Lancet Oncol 2011;12:913-922.

-2 Heideman DA, Lurkin I, Doeleman M, Smit EF, Verheul HM, Meijer GA, Snijders PJ, Thunnissen E, Zwarthoff EC: KRAS and BRAF mutation analysis in routine molecular diagnostics: comparison of three testing methods on formalin-fixed, paraffin-embedded tumor-derived DNA. J Mol Diagn 2012;14:247-255.

3 Miller AJ, Mihm MC: Melanoma. N Engl J Med 2006;355:51-65.

4 Thiam A, Zhao Z, Quinn C, Barber B: Years of life lost due to metastatic melanoma in 12 countries. J Med Econ 2016;19:259-264.

5 Chapman PB, Hauschild A, Robert C, Haanen JB, Ascierto P, Larkin J: Improved survival with vemurafenib in melanoma with BRAF V600E mutation. N Engl J Med 2011;364:2507-2516.

-6 Davies H, Bignell GR, Cox C, Stephens P, Edkins S, Clegg S, Teague J, Woffendin H, Garnett MJ, Bottomley W, Davis N, Dicks E, Ewing R, Floyd Y, Gray K, Hall S, Hawes R, Hughes J, Kosmidou V, Menzies A, Mould C, Parker A, Stevens C, Watt S, Hooper S, Wilson R, Jayatilake H, Gusterson BA, Cooper C, Shipley J, Hargrave D, Pritchard-Jones K, Maitland N, Chenevix-Trench G, Riggins GJ, Bigner DD, Palmieri G, Cossu A, Flanagan A, Nicholson A, Ho JW, Leung SY, Yuen ST, Weber BL, Seigler HF, Darrow TL, Paterson H, Marais R, Marshall CJ, Wooster R, Stratton MR, Futreal PA: Mutations of the BRAF gene in human cancer. Nature 2002;417:949954.

7 Ribas A, Flaherty KT: BRAF targeted therapy changes the treatment paradigm in melanoma. Nat Rev Clin Oncol 2011;8:426-433. 


\section{Case Reports in Oncology}

\begin{tabular}{l|l}
\hline Case Rep Oncol 2016;9:241-245 \\
\hline DOI: 10.1159/000445939 & $\begin{array}{l}\text { (c) 2016 The Author(s). Published by S. Karger AG, Basel } \\
\text { www.karger.com/cro }\end{array}$ \\
\hline
\end{tabular}

Zepeda-Lopez et al.: BRAF Mutation (V600E) Prevalence in Mexican Patients Diagnosed with Melanoma

8 Houben R, Becker JC, Kappel A, Terheyden P, Bröcker EB, Goetz R, Rapp UR: Constitutive activation of the Ras-Raf signaling pathway in metastatic melanoma is associated with poor prognosis. J Carcinog 2004;3:6.

-9 Hauschild A, Grob JJ, Demidov LV, Jouary T, Gutzmer R, Millward M, Rutkowski P, Blank CU, Miller WH Jr, Kaempgen E, Martín-Algarra S, Karaszewska B, Mauch C, Chiarion-Sileni V, Martin AM, Swann S, Haney P, Mirakhur B, Guckert ME, Goodman V, Chapman PB: Dabrafenib in BRAF-mutated metastatic melanoma: a multicentre, open-label, phase 3 randomised controlled trial. Lancet 2012;380:358-365.

10 Ernstoff MS: Been there, not done that - melanoma in the age of molecular therapy. N Engl J Med 2011;364: 2547-2548.

11 Yu L, Favoino E, Wang Y, Ma Y, Deng X, Wang X: The CSPG4-specific monoclonal antibody enhances and prolongs the effects of the BRAF inhibitor in melanoma cells. Immunol Res 2001;50:294-302.

-12 Riveiro-Falkenbach E, Villanueva CA, Garrido MC, Ruano Y, García-Martín RM, Godoy E, Ortiz-Romero PL, Ríos-Martín JJ, Santos-Briz A, Rodríguez-Peralto JL: Intra- and inter-tumoral homogeneity of BRAF(V600E) mutations in melanoma tumors. J Invest Dermatol 2015;135:3078-3085.

13 Yaman B, Kandiloğlu G, Akalin T: BRAF-V600 mutation heterogeneity in primary and metastatic melanoma: a study with pyrosequencing and immunohistochemistry. Am J Dermatopathol 2016;38:113-120.

-14 Fajardo-Ramírez ÓR, Salas-Alanis JC, Guzmán-Huerta E, Martínez U, Barbosa Á, Patrick-Scott S, HernándezHernández JA, Villela LM: BRAF mutations among patients from the Northeast of México with malignant melanoma. Rev Invest Clin 2014;66:288-290.

15 Yancovitz M, Litterman A, Yoon J, Ng E, Shapiro RL, Berman RS, Pavlick AC, Darvishian F, Christos P, Mazumdar M, Osman I, Polsky D: Intra- and inter-tumor heterogeneity of BRAF(V600E) mutations in primary and metastatic melanoma. PLoS One 2012;7:e29336.

Table 1. Characteristics of the population analyzed

\begin{tabular}{|c|c|c|c|c|}
\hline Characteristic & $\mathrm{n}(\%)$ & $\begin{array}{l}\text { Frequency of } \\
B R A F \text {-positive } \\
\text { cases, n (\%) }\end{array}$ & $\begin{array}{l}\text { Frequency of } \\
B R A F \text {-negative } \\
\text { cases, n }(\%)\end{array}$ & $\mathrm{p}$ \\
\hline \multicolumn{5}{|l|}{ Sex } \\
\hline Male & $21(44.7)$ & $1(4.8)$ & $20(95.2)$ & \multirow[t]{2}{*}{ n.s. } \\
\hline Female & $26(55.3)$ & $2(7.7)$ & $24(92.3)$ & \\
\hline \multicolumn{5}{|l|}{ Anatomic site of the tumor } \\
\hline Head/face/neck & $9(19.1)$ & $1(11.1)$ & $8(88.9)$ & \multirow[t]{6}{*}{ n.s. } \\
\hline Trunk & $4(8.5)$ & $0(0.09)$ & $4(100)$ & \\
\hline Upper extremities & $10(21.3)$ & $0(0.0)$ & $10(100)$ & \\
\hline Lower extremities & $24(51.1)$ & $2(8.3)$ & $22(91.7)$ & \\
\hline Mucosa & $0(0.0)$ & $0(0.0)$ & $0(0.0)$ & \\
\hline Unknown & $0(0.0)$ & $0(0.0)$ & $0(0.0)$ & \\
\hline \multicolumn{5}{|l|}{ Clinical diagnosis } \\
\hline Nodular melanoma & $10(21.3)$ & $0(0.0)$ & $10(100)$ & \multirow[t]{6}{*}{ n.s. } \\
\hline Acral lentiginous melanoma & $28(59.6)$ & $2(7.1)$ & $26(92.9)$ & \\
\hline Superficial spreading melanoma & $9(19.1)$ & $1(11.1)$ & 8 (88.9) & \\
\hline Metastatic melanoma & $0(0.0)$ & $0(0.0)$ & $0(0.0)$ & \\
\hline Malignant melanoma & $0(0.0)$ & $0(0.0)$ & $0(0.0)$ & \\
\hline Otherwise specified & $0(0.0)$ & $0(0.0)$ & $0(0.0)$ & \\
\hline \multicolumn{5}{|l|}{ Breslow's thickness } \\
\hline$\leq 1.00 \mathrm{~mm}$ & $18(38.3)$ & $2(11.1)$ & $16(88.9)$ & \multirow[t]{3}{*}{0.343} \\
\hline$\geq 1.01 \mathrm{~mm}$ & $29(61.7)$ & $1(3.4)$ & $28(96.6)$ & \\
\hline Unknown & $0(0.0)$ & $0(0.0)$ & $0(0.0)$ & \\
\hline
\end{tabular}

BRAF-positive cases: $\mathrm{n}=3$ (6.4\%); BRAF-negative cases: $\mathrm{n}=44(93.6 \%)$.

n.s. $=$ Not significant. 